\title{
GENEZA I KONSEKWENCJE GLOBALNEGO KRYZYSU FINANSOWEGO 2008 ROKU. SIMMLOWSKIE INSPIRACJE
}

\author{
The 2008 global financial crisis - its genesis and consequences. Simmel's inspirations
}

\begin{abstract}
Streszczenie
W artykule przeprowadzono analizę przyczyn i skutków globalnego kryzysu finansowego, który wybuchł w 2008 r., w kontekście rozważań podjętych przez Georga Simmla w dziele Filozofia pieniądza. Niemiecki filozof żyjący na przełomie XIX i XX w. opisał istotną rolę pieniądza w procesach społecznych i jego wpływ na kształtowanie relacji społecznych. Zwracał uwagę na nieuczciwe praktyki w wymianie handlowej, które leżą u źródeł kryzysów finansowych. $Z$ tego powodu może zostać uznany za prekursora tego, co współcześnie określa się mianem etyki i społecznej odpowiedzialności biznesu oraz zrównoważonego rozwoju, a także krytyki nadmiernego liberalizmu rynkowego. W swoim dziele Simmel poruszył wiele problemów społeczno-ekonomicznych, z których niejeden jest aktualny po dziś.
\end{abstract}

Słowa kluczowe: relacje socjoekonomiczne, funkcje pieniądza, globalny kryzys finansowy, etyka biznesu, interwencjonizm państwowy, polityka monetarna

\begin{abstract}
The article analyzes the causes and effects of the global financial crisis that appeared in 2008 in the context of considerations undertaken by Georg Simmel in the Philosophy of Money. The German philosopher living at the turn of the $19^{\text {th }}$ and $20^{\text {th }}$ centuries described the important role of money in social processes and its impact on shaping social relations. He pointed out the unfair practices in trade that were at the root of financial crises. For this reason, he can be considered a precursor of what is now called ethics and corporate social responsibility and sustainable development, as well as a criticism of excessive market liberalism. In his work, Simmel raised many socio-economic problems, many of which are still relevant today.
\end{abstract}

Keywords: socio-economic relations, money functions, global financial crisis, business ethics, state intervention, monetary policy

\section{Wprowadzenie}

Wielu ekonomistów i inwestorów działających na rynkach finansowych próbuje odpowiedzieć na pytanie, czy można było przewidzieć globalny kryzys finansowy, który wybuchł w połowie września 2008 r., i jego skalę. W ciągu dekady pojawiły się liczne wyjaśnienia przyczyn powstania największego jak dotąd, jeśli chodzi o negatywne skutki, załamania systemu finansowego. Wśród źródeł wygenerowania wysokiego ryzyka kredytowego wskazuje się na: czynniki związane z zastosowaniem derywatów w działalności inwestycyjnej banków, nieprzestrzeganiem procedur bezpieczeństwa i rzetelności przeprowadzania procesów badania zdolności kredytowej osób wnioskujących o kredyty hipoteczne, wzrost deregulacji w funkcjonowaniu rynków kapitałowych i banków inwestycyjnych, zbyt długo utrzymywane niskie stopy procentowe przez Bank Rezerw Federalnych w Nowym Jorku (Fed) i wiele innych czynników, które rozwijały się w ostatnich 
dekadach przed zapaścią (Prokopowicz 2018: 124-125). W znacznym stopniu przebadano mikro-, mezo- i makroekonomiczne determinanty kryzysu finansowego i gospodarczego. Skoncentrowano się na działalności banków inwestycyjnych, banków centralnych, organów nadzoru nad systemami finansowymi, wskazano na niewłaściwe posługiwanie się derywatami przez banki inwestycyjne, na niedoskonałości w kwestii zarządzania ryzykiem kredytowym itd. W pewnych aspektach w niektórych krajach poprawiono procedury udzielania kredytów i systemu identyfikacji ryzyka kredytowego. Niektóre banki inwestycyjne zapłaciły kary finansowe za posługiwanie się informacjami typu insider trading. Inne zapłaciły kary dlatego, że z jednej strony przyczyniły się do podniesienia skali negatywnych skutków globalnego kryzysu, a z drugiej zarabiały na spadkach cen akcji. Przy czym kary były wielokrotnie mniejsze niż osiągnięte w nieetyczny sposób zyski. Słowo „nieetyczne” jest w kontekście niniejszych rozważań słowem kluczowym.

Nie był to pierwszy kryzys, który rozpoczął się od krachu giełdowego, a skończył wzrostem zadłużenia w finansach publicznych wielu krajów, dużym wzrostem bezrobocia oraz spadkiem dochodów obywateli, konsumpcji i inwestycji, ale pod względem skali nieetycznego przestrzegania procedur w bankach, szczególnie przez sprzedawców produktów kredytowych i inwestycyjnych - istotnego czynnika wzrostu systemowego ryzyka kredytowego - był wyjątkowy. W analizie źródeł kryzysu 2008 r. oraz czynników kryzysogennych na kwestie etyczne zwracano uwagę w najmniejszym stopniu, a jednak powinny one być uwzględnione, jeśli funkcjonowanie systemów finansowych ma się poprawić. Niezbędna jest także wnikliwa analiza przyczyn oraz możliwości nieuczciwego realizowania procedur sprzedaży kredytowych i inwestycyjnych produktów bankowych, jakie miało miejsce w wielu bankach komercyjnych i inwestycyjnych głównie anglosaskiego modelu systemu finansowego i trwało przez minimum kilka lat poprzedzających ogłoszenie niewypłacalności i upadłości przez Lehman Brothers, czwarty co do wielkości bank inwestycyjny na świecie (Soboń, Prokopowicz, 2018: 268-269). Upadek tak potężnej instytucji finansowej był szokiem dla rynków finansowych, podważył nieformalną zasadę, że „duży nie może upaśc”, i wywołał efekt domina. Kryzys finansowy, początkowo rozwijający się głównie na rynkach giełd papierów wartościowych, szybko zaczął się przekształcać w kryzys zadłużenia wielu finansowych i niefinansowych podmiotów gospodarczych oraz finansów publicznych mniejszych gospodarek narodowych, szczególne krajów południa Europy, i w konsekwencji kryzys gospodarczy z klasycznymi znamionami w postaci wysokiego bezrobocia i spadku inwestycji, a w niektórych krajach pojawienia się także recesji gospodarczej (Chojan, Prokopowicz, Grzegorek, Matosek 2018: 346-347).

Liczne przykłady odwoływania się do tego, co dziś określa się mianem etyki biznesowej, społecznej odpowiedzialności biznesu oraz zasadami zrównoważonego rozwoju, można odnaleźć już w starożytności, gdy wysoko oprocentowane pożyczki ówczesnych złotników określano mianem lichwiarskich i niemoralnych. W przeszłości posługiwano się oczywiście innym nazewnictwem i znaczenie tych pojęć mogło być odmienne chociażby z tego względu, że opisane w literaturze procesy gospodarcze i pierwsze próby ich zinstrumentalizowanej i udokumentowanej analizy dotyczą ostatnich trzech wieków, tj. okresu datowanego od początków pierwszej rewolucji przemysłowej. Obecnie funkcjonujemy w czasie kolejnej rewolucji przemysłowej zwanej czwartą rewolucją technologiczną Przemysł 4.0, opartej na rozwoju i rosnącym zastosowaniu w różnych gałęziach przemysłu nowych, zinformatyzowanych technologii zaawansowanego przetwarzania informacji, takich jak: technologie bazodanowe Big Data, chmura obliczeniowa, machine learning, Internet rzeczy, sztuczna inteligencja, Business Intelligence oraz innych technologii zaawansowanego przetwarzania danych Data Mining. Jest to o tyle istotne w kontekście analizowanej problematyki, że bankowcy posądzani o stosowanie nieetycznych praktyk biznesowych wykorzystują ten argument do obrony podczas procesów wytaczanych przeciwko bankom, które doprowadziły do zwiększenia skali globalnego kryzysu finansowego w 2008 r. Dowodzą, że dzięki postępowi technologii informacyjnych możliwe jest tworzenie zaawansowanych modeli szacowania wartości zagrożonej na ryzyko kredytowe, podczas gdy tworzenie zinformatyzowanej inżynierii finansowej dotyczącej derywatów wyprzedziło procesy doskonalenia zarządzania ryzykiem kredytowym. Jednak to uzasadnienie zawiera w sobie niespójność logiczną. Otóż procesy doskonalenia zarządzania ryzykiem kredytowym również są zdeterminowane postępem w zakresie nowych technologii zaawansowanego przetwarzania informacji, więc jest to wielce wątpliwy i nadmiernie eksploatowany argument w tym przypadku (Soboń, Prokopowicz 2018: 271-272). 
Za prekursora rozważań etycznych w kontekście systemów finansowych, jakie znamy obecnie, możemy uznać Georga Simmla, niemieckiego intelektualistę żyjącego na przełomie XIX i XX w., uznawanego za jednego z pionierów socjologii. Autor Filozofii pieniądza wskazał w swoim dziele na kluczowe aspekty stosowania nieetycznych praktyk finansowych, których skutkiem są kryzysy gospodarcze i różnego rodzaju negatywne koszty społeczne (Przyłębski 1997: 2).

\section{Simmlowska charakterystyka relacji społeczno-finansowych końca XIX wieku}

Jak pisze Tomczok (2012), Filozofia pieniądza „ani nie przynależy do profesjonalnej wiedzy naukowej, ani też nie nawiązuje do bogatej tradycji literackich i filozoficznych opisów pieniądza. Nie jest to ani traktat z ekonomii politycznej, ani też literackie przedstawienie sytuacji handlowych. Zamiast tych sprawdzonych (nawet w 1900 r.) konwencji Simmel tworzy coś w rodzaju Krytyki ekonomicznego rozumu - próbuje pokazać znaczenie pieniądza dla ludzkiej podmiotowości oraz ująć współczesność jako epokę ukształtowaną przez mechanizm pieniądza”.

W swoim dziele, wydanym w 1900 r., Simmel wskazywał na istotną rolę pieniądza w procesach społecznych. Twierdził, że „tak jak zegar mierzy czas, tak pieniądz mierzy świat”", jest nie tylko środkiem ułatwiającym wymianę dóbr ekonomicznych w kontekście procesów gospodarczych, lecz także istotnym czynnikiem kształtującym relacje i interakcje wewnątrz społeczeństwa. Od czasu diagnozy poczynionej przez Simmla minęło ponad 100 lat. W okresie tym nastąpił spektakularny rozwój technologiczny i systemowy rynków finansowych, powstały nowe rodzaje banków i instrumentów finansowych, a tezy sformułowane w Filozofii pieniadza są nadal aktualne.

Według uczonego ewolucja pieniądza opiera się na dwóch założeniach: pieniądz jest obiektywnie istniejącym „symbolem relatywnego charakteru bytu” oraz „wyznacza miarę wszystkich rzeczy, nie będąc samemu przez nie mierzonym" i w związku z tym znajduje się w ciągłej autoalienacji (za: Bucholc 2019). Zdawać by się mogło, że ta druga teza po ponad 100 latach od wydania Filozofii pieniądza się zdezaktualizowała. Jednak niekoniecznie, ponieważ na początku XX w. na świecie panował, utrzymywany przez bankowość centralną, parytet złota, zgodnie z którym bank centralny mógł wyemitować i wprowadzić do obiegu pieniądz w ilości odpowiadającej zdeponowanemu kruszcowi złota w skarbcu banku centralnego. Parytet złota zapewniał wysoki poziom stabilności wartości waluty oraz relacji wartości walut reprezentujących gospodarki różnych krajów. Pieniądz w takim systemie nie mógł być dowolnie wedle potrzeb rządu dodrukowywany. W tak uformowanym systemie pieniężnym filozoficzno-holistycznie brzmiące koncepcje ekonomicznej i społecznej roli pieniądza z punktu widzenia współczesności wydają się nacechowane zbytnim patetyzmem i idealizmem. Jednak gdy uwzględnimy panujący w końcu XIX w. model wyjątkowo stabilnego systemu monetarnego opartego na parytecie złota, to okaże się, że twierdzenia Simmla mają logiczne uzasadnienie.

Niemiecki myśliciel twierdził, że za pośrednictwem pieniądza „niemal wszystkie stosunki między ludźmi mają postać wymiany" (za: Bucholc 2012). Nie ograniczał się jednak tylko do problematyki socjologicznej i ekonomicznej. Autor Filozofi pieniądza prowadził rozważania w ujęciu holistycznym, niemal transcendentalnym, analizując w przekroju epok „systemy prawne, monetarne, fiskalne, kodeksy obyczajowe i kanony estetyczne" (Bucholc 2012).

Jak wskazuje Marta Bucholc (2012), Simmel oddał w swoim opus magnum „pełny, pogłębiony i wszechstronny obraz społeczeństwa kapitalistycznego", choć kapitalizm nie był tematem jego dzieła, a jedynie „prostym następstwem pojawienia się i udoskonalenia wynalazku pieniądza”. Filozofia pieniądza, która powstała w epoce rewolucji przemysłowej oraz rozpoczynającej się kolejnej rewolucji technologicznej opartej na wynalazku elektryczności, w epoce rozwiniętego kapitalizmu, nie miała być wykładnią funkcjonowania pieniądza w kapitalistycznych strukturach rynkowych. Zarzucanie Simmlowi zbytniej filozoficzności wywodu wynika z braku głębszej analizy wnikliwości i trafności opisu dokonujących się procesów zmian społecznych i próby powiązania tych zmian ze zmieniającą się rolą pieniądza. Ponieważ procesy te trwały przez kolejne dziesiątki lat, a funkcjonalność pieniądza, chociażby z punktu widzenia bankowości centralnej,

1 https://teologiapolityczna.pl/filozofia-pieni-dza-georg-simmel [dostęp: 4.04.2019]. 
także podlegała określonym zmianom, można dostrzec w Filozofi pieniądza próbę opisu kontynuacji tych procesów. Na przykład gdy Simmel „przechodzi od rozważań w kategoriach substancji do badania funkcji: "pieniądzowi nadaje wartość nie to, czym jest, lecz to, do czego służy; [...] pieniądz zmierza do punktu, w którym stając się czystym symbolem, roztopi się w funkcji wymiany i pomiaru"” (Tomczok 2012).

Simmel pisał: „Korzyść, jaką czerpie pieniądz z odłączenia od wszelkich konkretnych treści i ruchów ekonomii, znajduje wyraz jeszcze w szeregu innych zjawisk, dla których typowe jest to, że nawet podczas silnych i rujnujących wstrząsów gospodarki dla tzw. ludzi pieniądza nic się zwykle nie zmienia, często nawet czerpią z tego korzyści w zwiększonej mierze. Zarówno gwałtowne spadki cen, jak i nieprzytomne hossy mogą być przyczyną wielu załamań i zniszczenia podstaw egzystencji. Doświadczenie pokazało jako regułę, że wielcy bankierzy z tych przeciwstawnych niebezpieczeństw [...] dla wierzyciela i dłużnika, potrafili ciągnąć równomierne zyski” (za: Bucholc 2019). W tych słowach filozof zawarł istotę genezy globalnego kryzysu finansowego z początku XXI w. Gdy jesienią 2008 r. rozwijał się kryzys, niektóre banki inwestycyjne czerpały duże zyski z transakcji giełdowych podczas spadku cen papierów wartościowych, a wcześniej zarabiały na tych samych rynkach, gdy spekulacyjnie ceny papierów wartościowych bardzo rosły. W kontekście kolejnych kryzysów finansowych i gospodarczych, jakie pojawiały się od 1900 r., tj. od wydania Filozofii pieniądza, formułowane przez autora tezy dotyczące szkodliwości społecznej stanu głębokiej nierównowagi na rynkach giełd papierów wartościowych są nadal aktualne. Dodać należy, że głęboka nierównowaga na rynkach giełd papierów wartościowych stanowiła zwykle pierwszy etap rozwoju kryzysów finansowych i gospodarczych, w tym także tych największych, tj. Wielkiego Kryzysu w latach 1929-1934 oraz globalnego kryzysu finansowego 2008 r. Pomiędzy nimi, szczególnie od początku lat 70. XX w. wystąpiło kilka kryzysów finansowych i gospodarczych, charakteryzujących się globalnym zasięgiem z nieco mniejszymi negatywnymi skutkami społecznymi i gospodarczymi oraz znacznie więcej kryzysów lokalnych i krajowych.

Należy podkreślić, że filozof z przełomu wieków zauważył negatywne dla społeczeństwa i gospodarki skutki silnego rozchwiania na rynkach giełdowych wycen różnych aktywów kapitałowych, wytrącenia rynków giełdowych z równowagi i wzrostu amplitudy zmian cen notowanych na giełdach instrumentów inwestycyjnych, żyjąc w epoce braku informatyzacji procesów realizowanych na rynkach finansowych, braku rozwiniętej polityki keynesowskiego interwencjonizmu państwowego (Domańska-Szaruga, Prokopowicz, 2015: 38-39), braku derywatów wykorzystywanych przez banki inwestycyjne w procesach zarządzania ryzykiem kredytowym, relatywnie niewielkiego udziału bankowości inwestycyjnej w transakcjach zawieranych na rynkach kapitałowych oraz w sytuacji niewielkiego rynku papierów wartościowych nabywanych przez obywateli. Od lat 70. XX w. w związku z liberalizacją procedur zawierania transakcji finansowych i deregulacją rynków finansowych rośnie ryzyko destabilizacji sytuacji na rynkach kapitałowych, w tym przede wszystkim na giełdach papierów wartościowych (Prokopowicz 2015: 21-22). Z tego powodu autor Filozofi pieniądza może być uznany za prekursora krytyki nadmiernego liberalizmu rynkowego. W jego rozpoznaniach można odczytać sugestię poprawienia funkcjonowania rynków giełd papierów wartościowych, co świadczyłoby o prekursorskim podejściu XIX-wiecznego myśliciela, biorąc pod uwagę, że nie istniały wówczas instytucje nadzoru nad systemami finansowymi. Pierwsza Komisja Papierów Wartościowych i Giełd powstała w Stanach Zjednoczonych dopiero w reakcji na Wielki Kryzys.

Problematyka Filozofii pieniądza obejmuje wiele różnych zagadnień, takich jak:

- działalność ekonomiczna jako tworząca i zarazem pokonująca dystanse,

- wymiana jako środek przezwyciężenia czysto subiektywnego znaczenia wartości przedmiotu,

- wymiana jako wzajemne wyrażanie wartości rzeczy,

- wymiana jako forma życia oraz jako warunek wartości ekonomicznej,

- wartość ekonomiczna a relatywistyczny obraz świata,

- analiza natury pieniądza w odniesieniu do stałości jego wartości, jego rozwoju i obiektywności,

- rozwój czysto symbolicznego charakteru pieniądza,

- podaż pieniądza i polityka monetarna,

- spadające znaczenie pieniądza jako substancji i rosnące znaczenie pieniądza jako wartości,

- pieniądz jako najskrajniejszy przykład środka stającego się celem,

- psychologiczne następstwa teleologicznej pozycji pieniądza, 
- rozwój kulturowy a międzyludzkie relacje społeczne,

- relacje między gospodarką pieniężną a zasadą indywidualizmu,

- przekształcenie konkretnych praw w roszczenia pieniężne,

- wynagrodzenie za pracę i jego uzasadnienie,

- zapośredniczona przez gospodarkę pieniężną przewaga funkcji intelektualnych nad emocjonalnymi,

- stosunek pieniądza do racjonalności prawa i logiki,

- tempo życia, jego zmiany oraz zmiany zasobów pieniężnych.

\section{Postsimmlowska analiza źródeł globalnego kryzysu finansowego 2008 roku}

W ciągu dekady, która minęła od wybuchu kryzysu w 2018 r., przeprowadzono liczne analizy mające na celu ocenę przeprowadzonych interwencjonistycznych rządowych programów antykryzysowych, działań służących ratowaniu kluczowych podmiotów gospodarki przed upadłością finansową oraz aktywizowaniu popytu, inwestycji, produkcji, jak również płynności na rynku kredytowym. Obecnie, biorąc pod uwagę zrealizowane z sukcesem w tym zakresie interwencjonistyczne działania w gospodarce amerykańskiej, wynik tych ocen jest łatwy do przewidzenia. Otóż pozytywnie ocenia się znaczący spadek bezrobocia i wzrost popytu na dobra konsumpcyjne i nieruchomości (Domańska-Szaruga, Prokopowicz 2015: 39). Jednak uratowanie gospodarki przed być może znacznie większą potencjalnie zapaścią koniunktury nie jest wystarczającym rozwiązaniem (Gwoździewicz, Prokopowicz 2015a: 205-206). Część ekonomistów twierdzi, że zalążki kryzysu zaczęły się pojawiać już pod koniec lat 90. ubiegłego wieku w związku z liberalizacją polityki kredytowej banków komercyjnych udzielających kredytów konsumpcyjnych, hipotecznych i inwestycyjnych, obniżaniem stóp procentowych przez bank centralny i pogłębianiem deregulacji odnośnie do funkcjonowania rynków finansowych i banków komercyjnych (Armijo 2001: 34). Szczególnie istotną rolę odegrała prezydentura Billa Clintona, podczas której zderegulowano rozdział bankowości inwestycyjnej i klasycznej bankowości depozy towo-kredytowej. Ustanowiony w latach $30 . \mathrm{XX}$ w. formalno-instytucjonalny rozdział tych dwóch rodzajów bankowości miał zwiększyć bezpieczeństwo systemowe w kontekście potencjalnych nowych kryzysów finansowych, których nigdy nie można wykluczyć (Prokopowicz 2003: 105). Liberalizacja regulacji prawnych w tym zakresie miała przyczynić się do stworzenia dodatkowych czynników prorozwojowych dla gospodarki. W praktyce jednak okazała się czynnikiem prorozwojowym głównie dla rynków finansowych, tj. stworzyła warunki tworzenia się baniek spekulacyjnych na rynkach giełd papierów wartościowych, surowcowych i innych, w które inwestują globalnie działające fundusze inwestycyjne (Dmowski, Prokopowicz 2010: 84).

W sytuacji braku szybkiej interwencji ze strony rządów krajów wysoko rozwiniętych kryzys 2008 r. mógł doprowadzić do długotrwałej dekoniunktury na rynkach finansowych, braku zaufania klientów do systemu bankowego i w konsekwencji do recesji w krajowych gospodarkach, a w skrajnie negatywnych scenariuszach do silnego załamania systemu finansowego, którego negatywne skutki są obecnie trudne do oszacowania. Już na samym początku rozwoju kryzysu obraz dekoniunktury krajowej gospodarki był dramatyczny. W październiku 2008 r. recesja gospodarki Stanów Zjednoczonych sięgnęła niemal 7\%. Był to największy spadek wzrostu gospodarczego od II wojny światowej. Prawdopodobnie sytuacja mogłaby wyglądać znacznie gorzej, gdyby nie sięgnięto po znany i szybko wprowadzony w nieco zmodyfikowanej formule keynesowski interwencjonizm państwowy (Soboń, Prokopowicz 2018: 268-269).

Lobby bankowe w porozumieniu z rządami poszczególnych krajów uznało, że nie można dopuścić do pogłębienia kryzysu. Utworzone natychmiast po upadku Lehman Brothers zespoły kryzysowe składające się z reprezentantów nadzoru bankowego, największych instytucji finansowych i banków centralnych konsultowały i następnie rekomendowały do szybkiego wdrożenia programy interwencjonizmu państwowego, w których największą rolę miały odegrać banki centralne (Bonner, Wiggin 2009: 62). W ramach programów antykryzysowych skierowanych bezpośrednio do sektora bankowego obniżano stopy procentowe, udzielano pożyczek bankom komercyjnym i innym instytucjom finansowym na preferencyjnych warunkach, dokapitalizowywano kluczowe dla krajowej gospodarki duże przedsiębiorstwa tracące płynność finansową w zamian za przejmowanie udziałów w akcjach tychże podmiotów i wymuszano wprowadzanie programów restrukturyzacji. Poza tym kluczowe również w kontekście gospodarki globalnej banki centralne jak Fed 
i Europejski Bank Centralny (EBC) w ramach interwencjonistycznych działań antykryzysowych prowadziły przez kilka lat skup obciążonych najwyższymi poziomami ryzyka kredytowego tzw. śmieciowych aktywów finansowych od banków komercyjnych, zapewniając w ten sposób utrzymanie płynności w systemie finansowym (Prokopowicz 2016: 26-27).

Obecnie wśród ekonomistów przeważa pogląd, że gdyby nie zastosowanie szybkiego interwencjonizmu państwowego - nawiązującej do znanej już od lat 30. ubiegłego wieku formuły keynesizmu - skala spowolnienia gospodarczego świata i poszczególnych krajów byłaby znacznie większa (Płókarz 2013: 83). W ramach prorozwojowych działań interwencjonizmu państwowego Fed stosował łagodną politykę monetarną niskich stóp procentowych oraz program aktywizowania akcji kredytowej i utrzymania płynności w systemie finansowym poprzez finansowanie skupu od banków komercyjnych najbardziej zagrożonych aktywów (Szybowski, Prokopowicz, Goździewicz, 2016: 141-142). Od kilku lat widać już trwałe makroekonomiczne oznaki poprawy sytuacji gospodarczej sugerujące, że realizowana przez Baracka Obamę polityka ożywania gospodarki ze środków publicznych oraz aktywna polityka monetarna Fed osiągnęły zamierzone cele. Miarą tych efektów jest znacząca poprawa sytuacji na rynku pracy. Odnotowano duży spadek stopy bezrobocia - z ponad 14\% pod koniec 2008 r. do poniżej 7\% już w listopadzie 2013 r. oraz poniżej 4\% w kwietniu 2018 r. (Szymański 2018). Nadal jednak znaczna część ekonomistów wskazuje, że prowadzona w ten sposób interwencjonistyczna polityka gospodarcza sprowadza się głównie do „kupowania czasu”, po którym powinny nastąpić kolejne etapy poprawy sytuacji gospodarczej kraju i znaczący wzrost wpływów do budżetu, obecnie obciążonego rekordowo wysokim deficytem budżetowym przekraczającym 4\% PKB. Niekorzystnym czynnikiem, obrazującym nie najlepszy stan finansów publicznych, jest rosnący w Stanach Zjednoczonych dług publiczny, który w 2015 r. przekroczył nominalnie 17 bilionów dolarów, a obecnie kształtuje się na poziomie niemal 19 bilionów dolarów i z tą wartością znacznie przekracza 110\%. PKB. Donald Trump zapowiedział, że będzie kontynuował w polityce gospodarczej programy interwencjonizmu państwowego, jednak ukierunkowane bardziej na realną gospodarkę, a nie tylko rynki finansowe i sektor bankowy².

W mediach dominuje przekaz umniejszający odpowiedzialność banków inwestycyjnych za kryzys i wskazujący na bankowość centralną jako głównego winowajcę. Jest to wygodne dla bankowości inwestycyjnej, ponieważ zdejmuje z niej obowiązek doskonalenia procesu zarządzania ryzykiem kredytowym, którego celem powinno być niedoprowadzanie do baniek spekulacyjnych na zderegulowanych rynkach kapitałowych. Społeczeństwu próbuje się wmówić, że to w Fed głównie od połowy lat 90., tj. za kadencji Alana Greenspana oraz Bena Bernanke, do jesieni 2008 r. była stosowana polityka aktywizowania procesów gospodarczych poprzez obniżkę stóp procentowych banku centralnego (Gwoździewicz, Prokopowicz 2016: 93-94). Jednak to tylko teoria, ponieważ sukcesywnie obniżane stopy procentowe szybciej generowały inflację aktywów notowanych na rynkach kapitałowych, niż pobudzały przedsiębiorstwa do inwestycji technologicznych i restrukturyzacyjnych. Jeżeli pojawiało się zagrożenie przewartościowania na którymś z rynków i ryzyko krachu giełdowego, to wówczas Alan Greenspan ogłaszał, że kolejna obniżka stóp procentowych okaże się lekarstwem na pierwsze symptomy ewentualnej choroby.

Krytycznym sygnałem ostrzegawczym była bańka spekulacyjna wycen akcji dotcomów na giełdzie nowojorskiej na przełomie wieków, jednak osoby zatrudnione w Komitetach ds. Rezerwy Federalnej w amerykańskim banku centralnym zamiast podjąć racjonalne decyzje słuchały parafilozoficznych teorii szefa Fedu, traktowanego jak nieomylna wyrocznia. Pod tym względem sytuacja wyglądała tak, jakby kondycja całej globalnej gospodarki, będąc zdeterminowana koniunkturą na rynkach kapitałowych, przez kilka lat w znaczącym stopniu uwarunkowana była tym, co ogłosi jeden człowiek. Co za paradoks w gospodarce uznawanej za najbardziej urynkowioną i demokratyczną. Alan Greenspan, zwolennik wolnego rynku i leseferyzmu, stosował na dużą skalę interwencjonizm państwowy pośrednio skierowany na całą gospodarkę, a bezpośrednio działał na rynki kapitałowe, prowadząc nieuchronnie do bańki spekulacyjnej o rozmiarach niespotykanych nigdy wcześniej (Prokopowicz 2015: 21-22). Działo się to mimo wielokrotnych ostrzeżeń ekonomistów niezależnych od instytucji finansowych, którzy już na początku XXI w. alarmowali, że na

2 http://biznes.onet.pl/wiadomosci/swiat/przemowienie-donalda-trumpa-przed-kongresem/st3yqv [dostęp: 1.03.2017]. 
rynkach papierów wartościowych, w tym pochodnych kredytowych obligacji subprime oraz w zakresie cen nieruchomości, rośnie nowa bańka spekulacyjna (Bonner, Wiggin 2006: 295).

Nawet na moment przed ogłoszeniem upadłości przez Lehman Brothers, gdy problem był już ewidentnie widoczny, stopa bezrobocia rosła, udzielano Amerykanom niemającym zdolności kredytowej kredytów hipotecznych, ceny nieruchomości spekulacyjnie windowały do góry, wzrost gospodarczy Stanów Zjednoczonych wykazywał wyraźną tendencję spadkową, a Fed forsował jedyną receptę na rosnące ryzyko systemowe obejmujące niemal cały system finansowy, tj. obniżkę stóp procentowych. Czyżby szef Fedu uznał, że ceny aktywów na rynkach kapitałowych mogą rosnąć w nieskończoność w tempie geometrycznym? Takie można odnieść wrażenie, analizując wykresy indeksów giełdowych i ceny nieruchomości w latach 90. aż do 2008 r. Dziś wiemy, że tego typu strategia polegająca na uznaniu niskich stóp procentowych za uniwersalne lekarstwo na wszelkie poważniejsze choroby krajowej gospodarki okazała się błędna (Bliss, Kaufman 2010: 196).

Obecnie ekonomiści próbują odpowiedzieć na pytanie, czy popełnione błędymożna jeszcze w pełni naprawić, czy jednak globalne rynki finansowe zmierzają nieuchronnie do kolejnego spektakularnego krachu i tym samym do globalnego kryzysu finansowego. Powszechnie panuje pogląd, że bank centralny Stanów Zjednoczonych zbyt długo stosował łagodną politykę monetarną, utrzymując stopy procentowe pożyczek udzielanych bankom komercyjnym na poziomie 1\%. Jednak analiza źródeł globalnego kryzysu finansowego 2008 r. nie powinna głównie dotyczyć wskazywania winnych w bankowości centralnej Stanów Zjednoczonych. Nie można zapominać o równie istotnej kwestii dotyczącej działalności kredytowej na poziomie transakcyjnym, jaką jest potrzeba doskonalenia procesu zarządzania ryzykiem kredytowym w bankach komercyjnych, zarówno w klasycznych depozy towo-kredytowych, hipotecznych, jak i inwestycyjnych (Prokopowicz 2008: 88-89). Banki nie będą same efektywnie realizować tego procesu w sytuacji zderegulowanych rynków finansowych, a szczególnie wyłączonym z wielu regulacji derywatów. Niezbędne jest w tym zakresie wzmocnienie instytucji nadzoru bankowego nie tylko w ujęciu krajowym, lecz także ponadnarodowym (Prokopowicz 2003: 97).

Dlaczego jednak kwestia potrzeby doskonalenia procesu zarządzania ryzykiem kredytowym w bankach zeszła na plan dalszy w medialnych dyskusjach? Otóż dlatego, że obecnie przyjmuje się, iż zastosowany w Stanach Zjednoczonych pakiet interwencjonistycznych działań antykryzysowych wywołał oczekiwane, pozytywne skutki przywrócenia wzrostu gospodarczego w gospodarce amerykańskiej. Nie jest jednak jeszcze przesądzone, że zastosowanie analogicznych programów interwencji antykryzysowych w innych krajach przyniesie podobne pozytywne efekty, biorąc pod uwagę specyfikę tej gospodarki, tj. wysoki poziom urynkowienia procesów gospodarczych i anglosaski model systemu finansowego. Od kilku lat niektóre analogiczne działania interwencjonistyczne stosuje w Europie EBC. W marcu 2016 r. zwiększono sumę środków finansowych z 60 do 80 mld euro przeznaczanych w wymiarze miesięcznym na wspomaganie płynności finansowej w systemie finansowym Eurolandu. Jednak trzeba pamiętać, że Unię Europejską tworzą co prawda ujednolicane systemowo i rynkowo, ale jednak znacząco zróżnicowane kraje pod względem potencjału wytwórczego, wyposażenia w określone kategorie czynników produkcyjnych oraz w zakresie regulacji dotyczących systemów fiskalnych i elektronicznego transferu kapitału (Dmowski, Prokopowicz, Sarnowski 2008: 132).

W mniejszych gospodarkach, z których część charakteryzuje się relatywnie niższą produktywnością i zwykle mniej efektywnym systemem fiskalnym, kryzys finansowy przybrał formę kryzysu zadłużeniowego finansów publicznych poszczególnych krajów (Koleśnik 2012: 69). Tak stało się w latach 2008-2014 przede wszystkim na południu Europy, tj. w Grecji, Hiszpanii, Portugalii i we Włoszech. Jednak kraje te nie są wyjątkami w kwestii znacznego wzrostu zadłużenia krajowych finansów publicznych. Kwestia ta dotyczy także niektórych najsilniej rozwiniętych gospodarek, czego przykładem są Stany Zjednoczone. W pierwszej fazie działań antykryzysowych publicznymi pieniędzmi ratowano banki inwestycyjne i towarzystwa ubezpieczeniowe, koncerny samochodowe i inne przedsiębiorstwa, które stanęły przed ryzykiem trwałej utraty płynności finansowej w obliczu wykazania ogromnych strat na wyniku finansowym. Szczególną rolę w tych antykryzysowych działaniach odegrały banki centralne poszczególnych krajów, a przede wszystkim Fed i EBC (Gwoździewicz, Prokopowicz 2015b: 209).

W związku z przeprowadzeniem powyższych działań globalny kryzys finansowy zasadniczo został zażegnany, ale pytania odnośnie do poprawy systemu finansowego nadal pozostały. Od początku 2013 r. 
sukcesywnie powraca akceptacja ryzyka na rynkach finansowych, co związane jest pośrednio z poprawiającymi się w ostatnich miesiącach danymi pochodzącymi z realnej gospodarki Stanów Zjednoczonych, przede wszystkim z amerykańskiego rynku pracy, na którym od jesieni 2012 r. obserwuje się poprawę, ponieważ w znacznej części gospodarki wzrost bezrobocia bardzo zwolnił, a w niektórych sektorach odnotowano pierwsze symptomy poprawy koniunktury. Zatrzymanie niekorzystnych tendencji zaobserwowano także na amerykańskich rynkach nieruchomości (Pietrzak 2012). Makroekonomiczne pierwsze symptomy poprawy koniunktury gospodarczej w Stanach Zjednoczonych pojawiły się już po ponad 4 latach usilnych starań centralnych ośrodków decyzyjnych, tj. organów władzy, w odniesieniu do kształtowania polityki fiskalnej i pieniężnej prowadzonej w gospodarce uznawanej jeszcze za największą w ujęciu globalnym.

Obecnie dominuje pogląd, że interwencjonistyczny keynesowski model działań antykryzysowych, uwzględniający podejmowane próby aktywizacji popytu konsumpcyjnego i inwestycyjnego, zastosowano w Stanach Zjednoczonych po raz kolejny z zasadniczo pozytywnymi skutkami. Kluczowym elementem tej interwencjonistycznej polityki gospodarczej była aktywna polityka monetarna Fedu. W kontekście pozytywnych efektów makroekonomicznych zastosowany pakiet pomocy z kluczowym udziałem bankowości centralnej można uznać za metodę sprawdzoną i skuteczną.

\section{Podsumowanie}

Simmel jest prekursorem myśli socjologiczno-ekonomicznej w kwestii nie tylko potencjalnych zagrożeń i związanych z tym kosztów społecznych i gospodarczych będących pochodną kolejnych kryzysów wywołanych głęboką destabilizacją sytuacji na giełdach papierów wartościowych, lecz także w kwestii potrzeby zorganizowania zinstytucjonalizowanych działań oraz instrumentów poprawy funkcjonowania giełd papierów wartościowych. Należy podkreślić, że w zakresie poprawy funkcjonowania giełd papierów wartościowych nie musi mieścić się znaczne ograniczenie liberalizacji działania tych rynków. Autor Filozofii pieniądza żył w epoce dominacji nurtów nawiązujących do ekonomii klasycznej, zgodnie z którą struktury rynkowe są w warunkach konkurencji sprawnie i obiektywnie działającymi mechanizmami powiązanych ze sobą określonych elementów tworzących określony rynek. Interwencjonizm państwowy rozwijany według koncepcji Johna Maynarda Keynesa pojawił się dopiero w latach 30. XX w. jako element poprawy działania pogrążonego w głębokim kryzysie organizmu krajowej gospodarki. Istotność tez zawartych w Filozofii pieniądza wynika także z tego, że problemy, na które wskazał autor, nie zostały nadal w pełni rozwiązane, a działanie systemów finansowych, w tym funkcjonowanie rynków giełd papierów wartościowych - w pełni poprawione. Gdyby tak się stało, a instytucje nadzoru nad systemami finansowymi działałyby w pełni efektywnie, to taki kryzys, jak w 2008 r., nie powinien się powtórzyć.

Podczas globalnego kryzysu finansowego 2008 r. negatywne aspekty zmaterializowały się w największym stopniu, a zdiagnozowane źródła tego kryzysu związane były ze zwiększoną różnymi czynnikami skalą ryzyka kredytowego współczesnych systemów finansowych. Wtórnym efektem istnienia wielu czynników systemowego ryzyka kredytowego jest kwestia wątpliwej stabilności systemów finansowych i możliwości pojawienia się podobnych kryzysów w przyszłości. Simmel spostrzegł ten problem już ponad 100 lat temu.

\section{Bibliografia}

Armijo L.E. (ed.) (2001), Financial globalization and democracy in emerging markets. Houndmills-BasingstokeNew York: Palgrave Macmillan Publishers.

Bliss R.R., Kaufman G.G. (ed.) (2010), Financial institutions and markets. The financial crisis: an early retrospective. Houndmills-Basingstoke-Hampshire-New York.

Bonner W., Wiggin A. (2009), The new empire of debt. The rise and fall of an epic financial bubble, second edition. Hoboken: John Wiley \& Sons.

Bucholc M. (2019), Bankierzy i tak wyjda na swoje. „Filozofia pieniądza” Georga Simmela. „Kultura Liberalna” 179, https://kulturaliberalna.pl/2012/06/12/bucholc-bankierzy-i-tak-wyjda-na-swoje-\%E2\%80\%9Efilozofia-pieniadza-georga-simmela. 
Chojan A., Prokopowicz D., Grzegorek J., Matosek M. (2018), The development of the banking system in Poland determined by the processes of adjustment to the normative and technological standards of The European Union and contemporary processes of economic and informational globalization. "International Journal of Legal Studies" 2(4), s. 339-367.

Dmowski A., Prokopowicz D. (2010), Rynki finansowe. Warszawa: Difin.

Dmowski A., Prokopowicz D., Sarnowski J. (2008), Finanse i bankowość. Teoria i praktyka. Warszawa: Difin.

Domańska-Szaruga B., Prokopowicz D. (2015), Makroekonomiczne zarządzanie antykryzysowe. "Zeszyty Naukowe Uniwersytetu Przyrodniczo-Humanistycznego w Siedlcach. Administracja i Zarządzanie” 34(107), s. 37-48.

Gwoździewicz S., Prokopowicz D. (2015a), Administrative, supervisory and legal determinants of globalization of financial markets and the banking system in Poland. "International Journal of New Economics and Social Sciences" 2(2), s. 203-216.

Gwoździewicz S., Prokopowicz D. (2015b), Importance and implementation of improvement process of prudential instruments in commercial banks on the background of anti-crisis socio-economic policy in Poland [w:] Globalization, the State and the Individual. "International Scientific Journal" 4(8), s. 149-161.

Gwoździewicz S., Prokopowicz D. (2016), Antykryzysowa aktywna polityka monetarna Banku Rezerw Federalnych w kontekście bezpieczeństwa systemu finansowego i koniunktury globalnej gospodarki. „Studia Administracji i Bezpieczeństwa” 1, s. 87-98.

Koleśnik J. (2012), Bezpieczeństwo systemu bankowego. Teoria i praktyka. Warszawa: Difin.

Kozieł H. (2018), USA: Niepotrzebny impuls fiskalny?, www.parkiet.com/Gospodarka---Swiat/302149993USA-Niepotrzebny-impuls-fiskalny.html\&template=restricted [dostęp: 14.02.2018].

Pietrzak M. (2012), Seria dobrych danych z USA, www.egospodarka.pl [dostęp: 28.12.2012].

Płókarz R. (2013), Globalne rynki finansowe. Praktyka funkcjonowania. Warszawa: Wydawnictwo Naukowe PWN.

Prokopowicz D. (2003), Regulacje Komitetu Bazylejskiego a modyfikacje systemów zarządzania ryzykiem kredytowym. Zeszyty Naukowo-Teoretyczne PWSBiA. „Wiek XXI. The 21st Century” 3(9), s. 95-114.

Prokopowicz D. (2008), Wzrost znaczenia zintegrowanego zarządzania ryzykiem w banku komercyjnym. „Zeszyty Naukowe Wyższa Szkoła Zarządzania i Prawa im. Heleny Chodkowskiej w Warszawie” 1 (28), s. 87-102.

Prokopowicz D. (2015), Improving managing the credit risk in conditions slowing economic growth. "International Journal of New Economics and Social Sciences" 1(1), s. 17-29.

Prokopowicz D. (2016), Social and economic determinants of the processes of economic globalization that shape the development of the banking system in Poland. "International Scientific Journal" 2(10), s. 19-32.

Prokopowicz D. (2018), A safe monetary central banking policy as a significant instrument for liquidity maintenance in the financial system. "International Journal of New Economics and Social Sciences" 2(8), s. 121-134.

Przyłębski A. (1997), Wstęp [w:] G. Simmel, Filozofia pieniądza. Poznań: Wydawnictwo Fundacji Humaniora.

Soboń J., Prokopowicz D. (2018), Anti-crisis state intervention and created in media images of global financial crisis. "International Journal of New Economics and Social Sciences" 2(8), s. 263-277.

Szybowski D., Prokopowicz D., Gwoździewicz S. (2016), Activating interventionist monetary policy of the European Central Bank in the context of the security of the European Financial System. "International Journal of New Economics and Social Sciences" 2(4), s. 138-146.

Szymański D. (2018), W USA bezrobocie jest najniższe od 18 lat, https://businessinsider.com.pl/twoje-pieniadze/ praca/bezrobocie-w-usa-maj-2018-r/p40mkst [dostęp: 1.06.2018].

Tomczok P. (2012), Nowoczesność pieniądza. „Znak” 689, http://www.miesiecznik.znak.com. pl/6892012pawel-tomczoknowoczesnosc-pieniadza. 